\title{
Article \\ The Response of Antioxidant System of Drought-Stressed Green Pea (Pisum sativum L.) Affected by Watering and Foliar Spray with Silica Nanoparticles
}

\author{
Rūta Sutulienè ${ }^{1, *(\mathbb{D})}$, Lina Ragelienè ${ }^{2}$, Giedrè Samuolienè ${ }^{1,3} \mathbb{D}$, Aušra Brazaityte் ${ }^{1}$, Martynas Urbutis 4 \\ and Jurga Miliauskienè ${ }^{1, *}$ \\ 1 Institute of Horticulture, Lithuanian Research Centre for Agriculture and Forestry, Kaunas Str. 30, \\ LT-54333 Babtai, Lithuania; giedre.samuoliene@lammc.lt (G.S.); ausra.brazaityte@lammc.lt (A.B.) \\ 2 Faculty of Natural Sciences, Vytautas Magnus University, Vileikos Str. 8, LT-44404 Kaunas, Lithuania; \\ lina.rageliene@vdu.lt \\ 3 Faculty of Agronomy, Agriculture Academy, Vytautas Magnus University, Studentu Str. 11, Akademija, \\ LT-52261 Kaunas, Lithuania \\ 4 UAB Ikarai, Vakaru Str. 6, LT-57238 Kèdainiai, Lithuania; Fitolab@ikarfactory.eu \\ * Correspondence: ruta.sutuliene@lammc.lt (R.S.); jurga.miliauskiene@lammc.lt (J.M.)
}

check for updates

Citation: Sutulienè, R.; Ragelienè, L.; Samuolienè, G.; Brazaitytè, A.; Urbutis, M.; Miliauskienè, J. The Response of Antioxidant System of Drought-Stressed Green Pea (Pisum sativum L.) Affected by Watering and Foliar Spray with Silica Nanoparticles. Horticulturae 2022, 8, 35. https://doi.org/10.3390/ horticulturae 8010035

Academic Editors: Othmane Merah, Purushothaman Chirakkuzhyil Abhilash, Magdi T. Abdelhamid, Hailin Zhang and Bachar Zebib

Received: 4 November 2021

Accepted: 28 December 2021

Published: 30 December 2021

Publisher's Note: MDPI stays neutral with regard to jurisdictional claims in published maps and institutional affiliations.

Copyright: (C) 2021 by the authors. Licensee MDPI, Basel, Switzerland. This article is an open access article distributed under the terms and conditions of the Creative Commons Attribution (CC BY) license (https:// creativecommons.org/licenses/by/ $4.0 /)$

\begin{abstract}
Abiotic stress caused by drought impairs plant growth and reduces yields. This study aimed to investigate the impact of silica nanoparticles $\left(\mathrm{SiO}_{2} \mathrm{NPs}\right)$ through the adverse effects of drought on the growth, oxidative stress, and antioxidative response of pea 'Respect'. Pea plants were grown in a greenhouse before being watered $\left(100 \pm 1 \mathrm{~mL}\right.$ per pot) or foliar sprayed (ca. $14 \pm 0.5 \mathrm{~mL} \mathrm{plant}^{-1}$ ) with suspensions containing $\mathrm{SiO}_{2} \mathrm{NPs}(0,12.5 \mathrm{ppm}, 25 \mathrm{ppm}$, and $50 \mathrm{ppm})$ and were exposed to drought stress for 10 days. Drought stress was created by maintaining $30 \%$ of the soil moisture while the control was $80 \%$. The growth parameters of pea grown under drought stress conditions were improved by spraying or watering plants with $\mathrm{SiO}_{2} \mathrm{NPs}(12.5,25$, and $50 \mathrm{ppm})$. At drought stress, peas treated with $\mathrm{SiO}_{2} \mathrm{NPs}$ (50 ppm) increased their relative water content by $29 \%$, specific leaf area by $17 \%$, and decreased root/shoot ratio by $4 \%$ as compared to plant non-treated with $\mathrm{SiO}_{2} \mathrm{NPs}$. In addition, spraying or watering of $\mathrm{SiO}_{2} \mathrm{NPs}$ increased peas tolerance to drought by increasing the activity of antioxidant enzymes at least three times including catalase, ascorbate peroxidase, glutathione reductase, and superoxide dismutase, as well as reducing hydrogen peroxide and lipid peroxidation in plant tissue. It was observed the increase in total phenolic compounds and nonenzymatic antioxidant activity (DPPH, ABTS, FRAP) in peas treated with $\mathrm{SiO}_{2} \mathrm{NPs}$ under drought stress. The physiological response of peas to drought and the effects of $\mathrm{SiO}_{2} \mathrm{NPs}_{\text {studied in this }}$ experiment based on the use of the concentration of $50 \mathrm{ppm}$ nanoparticles can protect peas from the damaging effects of drought and could help reduce global food shortages.
\end{abstract}

Keywords: antioxidant activity; drought; green pea; oxidative stress biomarkers; $\mathrm{SiO}_{2}$ nanoparticles

\section{Introduction}

Field peas play an important role in crop rotation due to their ability to fix atmospheric nitrogen in a symbiotic association with Rhizobium bacteria and fulfill the nitrogen demand of the succeeding crops, as well as can be used for both human food and animal feed. However, climate change has led to increased heterogeneity of precipitation, ranging from heavy to drought [1], leading to unstable crop yields and seed protein content, thus contributing to the reduction in field pea cultivation in the world according to Food and Agriculture Organization Statistics (FAOSTAT). To restore pea cultivation in the world, new ways such as nanotechnology need to be discovered to maintain a constant pea harvest regardless of environmental factors, as well as to maintain soil quality [2-5].

Nanoparticle (NPs), according to their unique properties: size, surface charge, shape, and potential interaction with plants could help to reduce the impact of drought [6]. It has 
been described that NPs ranging in size from 4 to $100 \mathrm{~nm}$ can cross the cuticle by disrupting the wax layer [7], and fluorescently tagged $>50 \mathrm{~nm}$ NPs can accumulate in the epidermis under the cuticle where stomata are absent $[7,8]$. Negatively charged plant cell walls act as an ion exchange surface that potentially promotes the penetration of cationic NPs rather than anionic NPs [9], but show much higher adsorption on the root surface of positively charged NPs [10]. With increasing interest in silica NPs $\left(\mathrm{SiO}_{2} \mathrm{NPs}\right)$, it has been found that $\mathrm{SiO}_{2} \mathrm{NPs}$ through symplastic and apoplastic pathways (through cell wall microchannels) penetrate the roots and then reach other parts of the plant through conductive tissues $[5,11]$.

Silicon (Si) is not essential for plants, but in drought stress, it can affect the water ratio in drought-affected plants, reduce stomatal conduction associated with protective cell turgor loss, improve the ability to extract water from the soil due to the promotion of root elongation and the regulation of aquaporin genes [12]. Si NPs can reduce oxidative stress by increasing antioxidant enzyme activities and decreasing reactive oxygen species (ROS) in plant leaf [7,13-15]. In a salinity experiment with sweet peppers and different forms of $\mathrm{Si}$, it was found that using $\mathrm{SiO}_{2} \mathrm{NPs}$ resulted in $15 \%$ higher plants, $34 \%$ higher fresh, and $36 \%$ dry biomasses and $11 \%$ higher total chlorophyll content and $30 \%$ yield compared to bulk Si [16]. In wheat seedlings, Si NPs (size 20-95 nm) were found to be more effective than bulk $\mathrm{SiO}_{2}$ in response to UV-B stress as well [17]; $\mathrm{Si}$ NPs successfully reduced lipid peroxidation by $82 \%$ and electrolyte leakage, as well as increased catalase (CAT) and superoxide dismutase (SOD) activity, resulting in increased antioxidant resistance of wheat to UV-B. More studies have demonstrated the effectiveness of $\mathrm{SiO}_{2} \mathrm{NPs}$ against abiotic stress in different plants. In strawberries, peroxide concentrations and total phenols, vitamin C, CAT, SOD, ascorbate peroxidase (APX), and glutathione peroxidase (GPX) were increased by spraying with $125 \mathrm{ppm} \mathrm{SiO}_{2}$ NPs under severe to moderate drought stress [14]. $\mathrm{SiO}_{2} \mathrm{NPs}$ had a positive effect on photosynthesis and gas exchange in rice seedlings [18]. Besides $30 \mathrm{ppm}$ of Si NPs foliar application reduced oxidative stress as evidenced by low levels of malondialdehyde (MDA) and electrolyte leakage and increased production of antioxidant enzymes such as SOD by $5 \%$, APX by $41 \%$, and CAT by $40 \%$ in rice tissues. In potatoes, increased GPX and SOD activity was observed after spraying with $50 \mathrm{ppm} \mathrm{SiO}_{2} \mathrm{NPs}$ under salinity stress [19]. Si NPs protected from oxidative stress in pea seedlings treated with $\mathrm{Cr}$ (VI) [20]; the application of $\mathrm{SiO}_{2} \mathrm{NPs}$ on $\mathrm{Cr}$ (VI) treated peas significantly increased the activity of enzymes such as SOD, APX, CAT, glutathione, and dehydroascorbate reductases. Another study [21] investigated the effects of $\mathrm{SiO}_{2} \mathrm{NPs}$ on marigold plants after spraying and watering them, observed that the CAT activity in plant leaves was higher when irrigated with the same concentration of $\mathrm{SiO}_{2} \mathrm{NPs}$ as compared to spray, but the opposite effect of the suspension was found for peroxidase-higher activity was found in sprayed plants.

In recent decades, the application of NPs to improve the resistance of various crops to abiotic stress was discussed, but there is still no consensus on the benefits of NPs for plant growth and yields. An array of plant species, different NPs, their particle size and concentrations, and application pathways have been used in the literature; however, knowing the beneficial role of Si to drought-affected plants [12], little data is available on the effects of $\mathrm{SiO}_{2} \mathrm{NPs}$ against drought stress in the Legumes family which are popular crops in the world. It was hypothesized that watering or foliar application of $\mathrm{SiO}_{2} \mathrm{NPs}$ alleviates oxidative stress in drought-affected peas by inducing non-enzymatic and enzymatic antioxidant activity. Therefore, the present study aimed to investigate the effect of watering and foliar application of different $\mathrm{SiO}_{2} \mathrm{NPs}$ concentrations on the growth traits of drought-affected green peas (Pisum sativum L.), to elucidate the influence of $\mathrm{SiO}_{2} \mathrm{NPs}$ on oxidative stress and antioxidative response in peas exposed to drought.

\section{Materials and Methods}

\subsection{Study Site and Treatments}

The research was carried out in a greenhouse $(3 \times 6 \mathrm{~m}, \mathrm{~h}=2 \mathrm{~m})$ at the Lithuanian Research Centre for Agriculture and Forestry, Institute of Horticulture, Babtai, Lithuania 
$\left(55^{\circ} 05^{\prime} 08.4^{\prime \prime} \mathrm{N} 23^{\circ} 48^{\prime} 03.5^{\prime \prime} \mathrm{E}\right.$, at an altitude of $51 \mathrm{~m}$; moderate climate zone of the northern hemisphere), from 6 May to 22 June. Before sowing, green pea (Pisum sativum L. cv. Respect, Maribo Seed International ApS, Holeby, Denmark) seeds were sterilized in 5\% sodium hypochlorite solution for $15 \mathrm{~min}$ to assure surface sterility and rinsed gently with deionized water several times. Then, seeds were soaked in water for $24 \mathrm{~h}$. Ten seeds were sown in 10-L volume plastic pots (7 pots per treatment, arranged randomized), filled with $\sim 8 \mathrm{~kg}$ of soil mixture (7:1 soil to perlite ratio, respectively). The granulometric composition of the soil was heavy loam, pH $7.4 \pm 0.1$; concentration of humus-3.6 $\pm 0.1 \% ; \mathrm{P}_{2} \mathrm{O}_{5}-243 \pm 8 \mathrm{mg} \mathrm{kg}^{-1}$; $\mathrm{K}_{2} \mathrm{O}-348 \pm 37 \mathrm{mg} \mathrm{kg}^{-1} ; \mathrm{NH}_{4}-4 \pm 0.6 \mathrm{mg} \mathrm{kg}^{-1} ; \mathrm{NO}_{3}-22 \pm 0.9 \mathrm{mg} \mathrm{kg}^{-1} ; \mathrm{SiO}_{2}-39 \pm$ $0.8 \mathrm{mg} \mathrm{kg}^{-1}$. Pea seedlings were thinned to 7 plants per pot 5 days after sowing. After 16 days of cultivation, the peas were fertilized with $7 \mathrm{~g} \mathrm{pot}^{-1}$ ammonium nitrate. Pots were irrigated with water by graduated cylinder daily to $80 \%$ of substrate moisture (SM) using substrate moisture sensor (Delta-T devices, HH2 moisture meter, Cambridge, UK) for 23 days (6 May till 12 June). In the greenhouse with a natural day length photoperiod, the average day/night temperature was $24.2 / 14.4{ }^{\circ} \mathrm{C}$; relative air humidity-54/75 $\pm 5 \%$ before exposure; during the drought treatment the average day/night temperature was $26.2 / 17.0^{\circ} \mathrm{C}$ and the relative air humidity was $50 / 73 \pm 5 \%$, data were measured throughout the experiment (Termio + data logger, Poland). When the peas reached the $40 \mathrm{BBCH}$ growth stage [22], they were watered $(100 \pm 1 \mathrm{~mL}$ per pot) or foliar sprayed until full wetting (ca. $14 \pm 0.5 \mathrm{~mL}_{\text {plant }}{ }^{-1}$ ) with solutions containing different concentrations of $\mathrm{SiO}_{2} \mathrm{NPs} 0$ (watered or sprayed with water, NPs-untreated), 12.5 ppm, 25 ppm, and 50 ppm. After the application of $\mathrm{SiO}_{2} \mathrm{NPs}$, the watering of pea plants was stopped and drought stress was initiated $(30 \% \mathrm{SM})$, while control plants were irrigated with water to maintain normal soil moisture (80\% SM) throughout the experiment. These regimes were applied for 10 days (12 June till 22 June) until harvest. Plants were harvested after reaching the BBCH 50 growth stage from each treatment to assess their morphophysiological responses.

$\mathrm{SiO}_{2} \mathrm{NPs}$ solutions were prepared with silica $\left(\mathrm{SiO}_{2}\right) \mathrm{NPs}$ (particle size: $20-30 \mathrm{~nm}$; purity: 99\%; US Research Nanomaterials, Inc, Houston, TX, USA). The NPs with concentrations of $12.5 \mathrm{ppm}, 25 \mathrm{ppm}, 50 \mathrm{ppm}$, were suspended in deionized (DI) water and ultrasonically dispersed for $60 \mathrm{~min}$. The NPs size and suspension stability were measured using Delsa ${ }^{\mathrm{TM}}$ Nano Submicron Particle Size (Beckman Coulter Instruments Corporation, Fullerton, CA, USA) and Zeta Potential device (Dispersion Technology Inc., Bedford Hills, NY, USA). The data in Table 1 show the negative charge of NPs in the suspensions and the stability of the systems, furthermore the NPs suspensions tend to be more monodisperse according to the polydispersity index (PDI).

Table 1. Properties of $\mathrm{SiO}_{2}$ NPs suspension in DI water $(\mathrm{pH}=7.05)$ : zeta potential, results represent the mean \pm standard error, polydispersity index, and percentage of nanoparticles between 1-100 $\mathrm{nm}$.

\begin{tabular}{cc}
\hline \multicolumn{2}{c}{ Suspension of $\mathrm{SiO}_{\mathbf{2}} \mathbf{~ N P s}$} \\
\hline Zeta potential $(\zeta ; \mathrm{mV})$ & $-20.64 \pm 0.333$ \\
Polydispersity index $(\mathrm{PI})$ & 0.34 \\
$\mathrm{NPs}$ size $1-100 \mathrm{~nm}$ in suspension $(\%)$ & 70 \\
\hline
\end{tabular}

\subsection{Relative Water Content, Specific Leaf Area, and Root/Shoot Ratio}

Ten pea plants were randomly selected from each treatment for biometric measurements. The shoots were separated from the roots and then fresh weight (FW) and dry weight (DW) were determined $(n=10)$. The FW and DW were measured with an electronic scale (Mettler Toledo AG64, Columbus, OH, USA) and DW was determined following forced-air convection drying at $105^{\circ} \mathrm{C}$ to a constant dry weight (Venticell 222, MBT, Brno, Czech Republic). After shoot FW determination, 10 matured plants per each treatment 
were floated on deionized water for $24 \mathrm{~h}$ and then turgid weights (TW) were measured. Relative water content (RWC) was calculated, using the following equation [23]:

$$
\text { RWC, } \%=\frac{(F W-D W)}{(T W-D W)} \times 100
$$

The leaf area was measured using an automatic leaf area meter (AT Delta-T Devices, Wallingford, UK) expressed as $\mathrm{cm}^{2} \mathrm{~g}^{-1}$. For calculation of specific leaf area (SLA), the total plant leaf area $(n=10)$ was divided by the shoot DW. Root/shoot ratio was determined as the ratio of root DW to aboveground DW.

\subsection{Antioxidant Properties and Total Phenolic Compounds}

Antioxidant properties of pea leaves were evaluated as the DPPH (2-diphenyl-1picrylhydrazyl), ABTS (2,2'-azino-bis (3-ethylbenzothiazoline-6-sulphonic acid)) diammonium salt, radical scavenging activities, and $\mathrm{Fe}^{2+}$ reducing antioxidant power assay (FRAP); the total contents of phenolic compounds were also determined. Extracts were prepared by grinding $0.3 \mathrm{~g}$ of plant leaves with liquid nitrogen and diluting with $5 \mathrm{~mL}$ of $80 \%$ methanol. After $24 \mathrm{~h}$, the samples were centrifuged for $10 \mathrm{~min}$ at $3000 \mathrm{rpm}$ (Hermle Z300K, Baden-Württemberg, Germany), extracts were filtered through cellulose filters and the supernatant was used for further analyses. All biochemical analysis was performed in 3 biological replications. Each of three biological replicates consisted of at least three conjugated plants and was repeated in three analytical replicates.

The total content of phenolic compounds was determined as gallic acid equivalents. A $250 \mu \mathrm{L}$ aliquot of the sample extract was mixed with $250 \mu \mathrm{L}$ of $10 \%(w / v)$ Folin-Ciocalteu reagent, $500 \mu \mathrm{L}$ of $1 \mathrm{M} \mathrm{Na}_{2} \mathrm{CO}_{3}$ solution, and $2 \mathrm{~mL}$ of distilled water [24]. After incubation for $20 \mathrm{~min}$ in the dark, the absorbance was measured at $765 \mathrm{~nm}$ (M501, Spectronic Camspec Ltd., Leeds, UK). The total phenolic compounds quantity $\mathrm{mg} \mathrm{g}^{-1}$ was calculated from the calibration curve of the gallic acid $\left(0.01-0.1 \mathrm{mg} \mathrm{mL}^{-1}, \mathrm{R}^{2}=0.99\right)$.

The ABTS (2,2'-azino-bis (3-ethylbenzothiazoline-6-sulphonic acid) radical cation was obtained by incubating the $7 \mathrm{mM}$ ABTS stock solution $(100 \mathrm{~mL})$ with $2.45 \mathrm{mM}$ potassium persulfate $\left(\mathrm{K}_{2} \mathrm{~S}_{2} \mathrm{O}_{8}\right.$; final concentration) and allowing the mixture to stand in the dark at room temperature for $12-16 \mathrm{~h}$ before use [25]. Thereafter, $50 \mu \mathrm{L}$ of the prepared sample was mixed with $2 \mathrm{~mL}$ of ABTS solution (ABTS stock solution was diluted 1:7) and the absorbance was measured after $11 \mathrm{~min}$ (plateau phase) at $734 \mathrm{~nm}$ (M501, Spectronic Camspec Ltd., Leeds, UK). The ABTS scavenging activity of pea leaves extracts was calculated as the difference between the initial absorbance and after reacting for $10 \mathrm{~min}$. A calibration curve was determined using Trolox (6-hydroxy-2,5,7,8-tetramethychroman-2-carboxylic acid; 97\% purity; Sigma-Aldrich, Burlington, MA, USA) as an external standard with a range of concentrations from 0.1 to $0.8 \mathrm{mM}\left(\mathrm{R}^{2}=0.99\right)$. It was expressed as ABTS $\mu \mathrm{mol}$ scavenged per $1 \mathrm{~g}$ of fresh weight $\left(\mu \mathrm{mol} \mathrm{g}^{-1} \mathrm{FW}\right)$.

For DPPH (2-diphenyl-1-picrylhydrazyl) assay, a stable $126.8 \mu \mathrm{M}$ DPPH (100\% purity; Sigma-Aldrich, Burlington, MA, USA) solution was prepared in methanol [26]. Subsequently, $1 \mathrm{~mL}$ of the DPPH solution was transferred to a test tube and mixed with $100 \mu \mathrm{L}$ of the diluted pea extract with $400 \mu \mathrm{L}$ methanol. The absorbance was scanned at $515 \mathrm{~nm}$ (M501, Spectronic Camspec Ltd., Leeds, UK) while reacting for $16 \mathrm{~min}$. The free radical scavenging capacity was expressed as $\mu \mathrm{mol}$ of DPPH radicals scavenged per $1 \mathrm{~g}$ of fresh weight $\left(\mu \mathrm{mol} \mathrm{g}{ }^{-1} \mathrm{FW}\right)$. A calibration curve was determined using Trolox (6-hydroxy-2,5,7,8tetramethychroman-2-carboxylic acid; 97\% purity; Sigma-Aldrich, Burlington, MA, USA) as an external standard with a range of concentrations from 0.1 to $0.6 \mathrm{mM}\left(\mathrm{R}^{2}=0.99\right)$.

The FRAP method is based on reducing ferric ion $\left(\mathrm{Fe}^{3+}\right)$ to ferrous ion $\left(\mathrm{Fe}^{2+}\right)$. The fresh working solution was prepared by mixing $300 \mathrm{mM}, \mathrm{pH} 3.6$ acetate buffer, $10 \mathrm{mM}$ TPTZ (2,4,6-tripyridyl-s-triazine) solution in $40 \mathrm{mM} \mathrm{HCl}$, and $20 \mathrm{mM} \mathrm{FeCl}_{3} \times 6 \mathrm{H}_{2} \mathrm{O}$ at 10:1:1 $(v / v / v)$ [27]. $20 \mu \mathrm{L}$ of the sample was mixed with $3 \mathrm{~mL}$ of working solution and incubated in the dark for $30 \mathrm{~min}$. Readings of the colored product (ferrous tripyridyl-triazine complex) were then taken at $593 \mathrm{~nm}$. A calibration curve was determined using $\mathrm{Fe}_{2}\left(\mathrm{SO}_{4}\right)_{3}$ (Iron 
(III) sulfate; 97\% purity; Sigma-Aldrich, Burlington, MA, USA) as an external standard with a range of concentrations from 0.005 to $0.5 \mathrm{mM}\left(\mathrm{R}^{2}=0.99\right)$. The antioxidant power is expressed as $\mathrm{Fe}^{2+}$ antioxidant capacity $\left(\mathrm{Fe}^{2+} \mu \mathrm{mol} \mathrm{g}{ }^{-1} \mathrm{FW}\right)$.

\subsection{Malondialdehyde and Hydrogen Peroxide}

The extracts used to determine the concentration of lipid peroxidation and hydrogen peroxide $\left(\mathrm{H}_{2} \mathrm{O}_{2}\right)$ in pea leaves were prepared by grinding $0.1 \mathrm{~g}$ of fresh sample with liquid nitrogen and diluting with $4 \mathrm{~mL}$ of $0.1 \%$ TCA (trichloroacetic acid). After centrifugation for $10 \mathrm{~min}$ at $3000 \mathrm{rpm}$ (Hermle Z300K, Baden-Württemberg, Germany), the supernatant was used for further analyses.

For $\mathrm{H}_{2} \mathrm{O}_{2}$ measurements in plant leaves, $500 \mu \mathrm{L}$ of the supernatant was added to $1 \mathrm{~mL}$ of $1 \mathrm{M}$ potassium iodide (KI). The absorbance of the mixture was scanned at $390 \mathrm{~nm}$ using a spectrophotometer (M501, Spectronic Camspec Ltd., Leeds, UK). A calibration curve was determined using $\mathrm{H}_{2} \mathrm{O}_{2}(30 \%$ hydrogen peroxide) as an external standard with a range of concentrations from $0.6-24.3 \mathrm{mM}\left(\mathrm{R}^{2}=0.99\right)$. The content of $\mathrm{H}_{2} \mathrm{O}_{2}$ is expressed in fresh weight ( $\left.\mu \mathrm{mol} \mathrm{g}{ }^{-1} \mathrm{FW}\right)$ [28].

The TBARS test determines malondialdehyde (MDA) content in pea leaves samples as the end product of lipid peroxidation. $500 \mu \mathrm{L}$ of the supernatant was added to $1 \mathrm{~mL}$ $0.5 \%(w / v)$ thiobarbituric acid (TBA) in $20 \%$ trichloroacetic acid (TCA). The mixture was incubated in boiling water for $30 \mathrm{~min}$. The reaction stopped after the samples have cooled. The samples were centrifuged at $10,000 \times g$ for $5 \mathrm{~min}$, and the absorbance of the supernatant was measured at $532 \mathrm{~nm}$ using a spectrophotometer (M501, Spectronic Camspec Ltd., Leeds, UK). The value for non-specific absorbance at $600 \mathrm{~nm}$ was subtracted [29]. The amount of MDA-TBA complex (red pigment) in leaves was calculated and expressed as nmol $\mathrm{g}^{-1} \mathrm{FW}$ :

$$
\mathrm{C}_{\mathrm{MDA}}=(\mathrm{A} 532-\mathrm{A} 600) / \mathrm{E}_{\mathrm{MDA}}
$$

$\mathrm{C}_{\mathrm{MDA}}$ - concentration of MDA, $\mu \mathrm{M}$

A532, A600-Absorbance at wavelengths

$\mathrm{E}_{\mathrm{MDA}}-\mathrm{MDA}$ extinction coefficient $155 \mathrm{mM}^{-1} \mathrm{~cm}^{-1}$

\subsection{Antioxidant Enzymes Activities}

The extracts used to determine the activity of superoxide dismutase (SOD), catalase (CAT), ascorbate peroxidase (APX), and glutathione reductase (GR) in pea leaves were prepared by grinding $0.5 \mathrm{~g}$ of fresh sample with liquid nitrogen and diluting within $5 \mathrm{~mL}$ extraction buffer (100 mM potassium-phosphate buffer, pH 7.8, containing $0.1 \mathrm{mM}$ EDTA). After centrifugation for $10 \mathrm{~min}$ at $3000 \mathrm{rpm}$ (Hermle Z300K, Baden-Württemberg, Germany), the supernatant was collected and used for the assays of enzymatic activities. All steps in the preparation of the enzyme extract were carried out at $4{ }^{\circ} \mathrm{C}$.

For soluble protein determination, the dye-binding method and bovine serum albumin as standard were used. A volume of $30 \mu \mathrm{L}$ of enzyme extract was mixed with $1.5 \mathrm{~mL}$ of Bradford reagent diluted by 1:5 with DI water. Absorbance was read after 2 min. through a spectrophotometer (M501, Spectronic Camspec Ltd., Leeds, UK) at $595 \mathrm{~nm}$ [30].

Total SOD activity was estimated by the inhibition of the photochemical reduction of nitroblue tetrazolium (NBT) by the enzyme [31]. Three $\mathrm{mL}$ of reaction mixture consisted of $13 \mathrm{mM}$ methionine, $75 \mu \mathrm{M}$ NBT, $100 \mathrm{mM}$ potassium phosphate buffer $(\mathrm{pH} 7.8$, containing $0.1 \mathrm{mM}$ EDTA), $50 \mu \mathrm{L}$ enzyme extract, and $13 \mu \mathrm{M}$ riboflavin. The tubes were under $150 \mu \mathrm{mol} \mathrm{m} \mathrm{m}^{-2} \mathrm{~s}^{-1}$ for $1 \mathrm{~min}$ to initiate the reaction and then covered. The absorbance was recorded after $30 \mathrm{~min}$ by spectrophotometer (M501, Spectronic Camspec Ltd., Leeds, UK) at $560 \mathrm{~nm}$, and one unit of enzyme activity was taken as that amount of enzyme, which reduced the absorbance reading to $50 \%$ in comparison with tubes lacking enzyme expressed as unit $\mathrm{mg}^{-1}$ protein $\mathrm{min}^{-1}$.

CAT activity was measured as the disappearance of $\mathrm{H}_{2} \mathrm{O}_{2}$ [32]. A volume of $100 \mu \mathrm{L}$ enzyme extract was added in $1.275 \mathrm{~mL}$ of $0.1 \mathrm{M}$ phosphate buffer $(\mathrm{pH} 7.8$, containing $0.1 \mathrm{mM}$ EDTA); the reaction started by adding $125 \mu \mathrm{L}$ of $30 \mathrm{mM} \mathrm{H}_{2} \mathrm{O}_{2}$. The decrease in 
absorbance measured by spectrophotometer (M501, Spectronic Camspec Ltd., Leeds, UK) at $240 \mathrm{~nm}$ was observed for $1 \mathrm{~min}$ and enzyme activity was computed by calculating the amount of $\mathrm{H}_{2} \mathrm{O}_{2}$ decomposed $\left(\mu \mathrm{mol} \mathrm{H}_{2} \mathrm{O}_{2} \mathrm{mg}^{-1}\right.$ protein $\left.\min ^{-1}\right)$.

APX activity was assayed by recording the decrease in optical density due to ascorbic acid at $290 \mathrm{~nm}$ [33]. The $1 \mathrm{~mL}$ assay mixture contained $0.1 \mathrm{M}$ potassium phosphate buffer (pH 7.8, containing $0.1 \mathrm{mM}$ EDTA), $0.5 \mathrm{mM}$ ascorbic acid, $0.1 \mathrm{~mL}$ enzyme extract, and $0.1 \mathrm{~mL}$ of $30 \mathrm{mM} \mathrm{H}_{2} \mathrm{O}_{2}$ was added to initiate the reaction. The decrease in absorbance was measured spectrophotometrically (M501, Spectronic Camspec Ltd., Leeds, UK) for $1 \mathrm{~min}$ and the extinction coefficient of $2.8 \mathrm{mM}^{-1} \mathrm{~cm}^{-1}$ for reduced ascorbate was used in

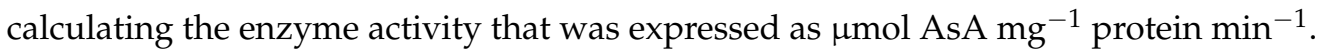

Measuring GR activity based on the rate of decrease in the absorbance of oxidized glutathione (GSSG), at $340 \mathrm{~nm}$ [34]. The reaction mixture contained $0.1 \mathrm{M}$ potassium phosphate buffer (pH 7.8, containing $0.1 \mathrm{mM}$ EDTA), 1 mM GSSG, $100 \mu \mathrm{L}$ enzyme extract and $75 \mu \mathrm{L} 0.1 \mathrm{mM}$ NADPH added last to initiate the reaction. The decrease in absorbance measured by spectrophotometer (M501, Spectronic Camspec Ltd., Leeds, UK) was recorded every $5 \mathrm{~min}$ until $20 \mathrm{~min}$. An absorption coefficient of $6.22 \mathrm{mM}^{-1} \mathrm{~cm}^{-1}$ was used for calculations, and GR activity was defined as $\mu \mathrm{mol} \mathrm{NADPH} \mathrm{mg}^{-1}$ protein $\mathrm{min}^{-1}$.

\subsection{Statistical Analysis}

All the values were expressed as mean \pm standard error. Data were analyzed using the Analysis of Variance (ANOVA) test followed by Tukey HSD at $p \leq 0.001$ to identify significant differences. All statistical analyses were performed using XLSTAT (Xlstat, Addinsoft, Paris, France, 2021).

\section{Results}

3.1. Effects of Drought Stress and $\mathrm{SiO}_{2} \mathrm{NPs}$ on Plants Specific Leaf Area, Relative Water Content, and Root/Shoot Ratio

The relative water content (RWC) and specific leaf area (SLA) decreased during drought stress (Figure 1a,b).

Drought stress significantly decreased SLA and RWC (38 and 27\%, respectively) compared with control plants. Watering or spraying peas with $\mathrm{SiO}_{2} \mathrm{NPs}(50 \mathrm{ppm})$ increased the values of these two parameters compared to plants watered or sprayed with water. Moreover, watering $\mathrm{SiO}_{2} \mathrm{NPs}$ had a better effect on SLA than spraying at all concentration levels.

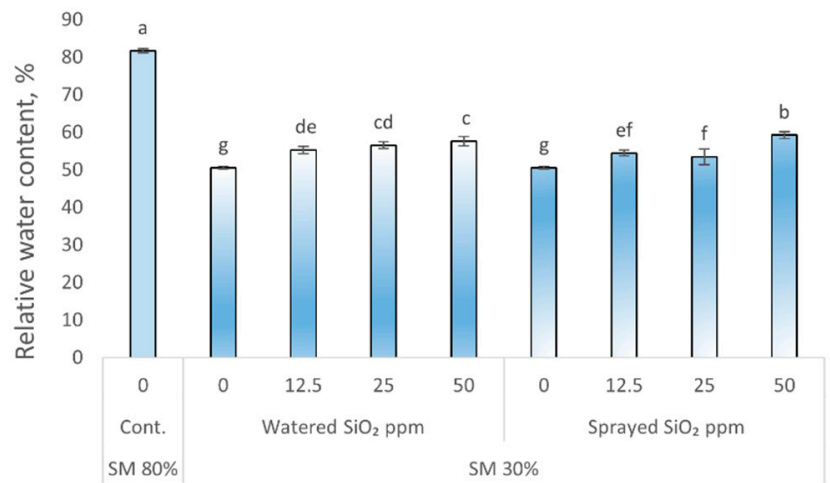

(a)

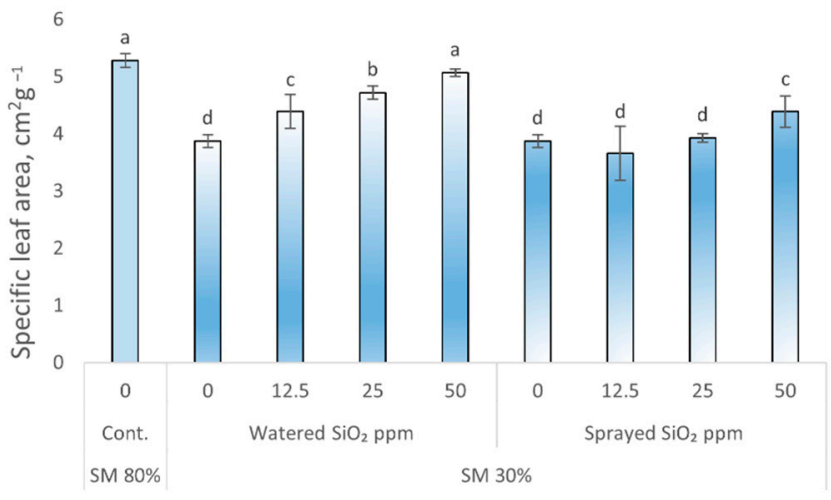

(b)

Figure 1. Cont. 


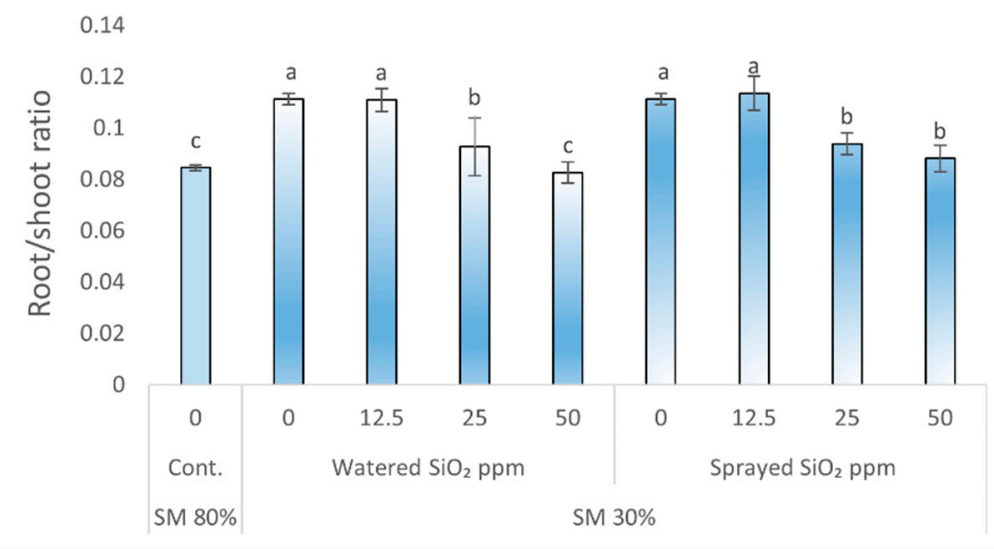

(c)

Figure 1. Effect of drought stress and $\mathrm{SiO}_{2} \mathrm{NPs}(0 ; 12.5 ; 25$; and $50 \mathrm{ppm})$ on relative water content (\%), specific leaf area $\left(\mathrm{cm}^{2} \mathrm{~g}^{-1}\right)$, and root/shoot ratio in P. sativum L. Cont.-control plants, substrate moisture (SM) 80\%; drought stress-SM 30\%, RWC (a); specific leaf area (b); root/shoot ratio (c). Values are mean \pm SE of 10 replicates and different letters are differed significantly by Tukey HSD Test $(p<0.001)$.

There was a statistically significant increase in the root/shoot ratio (Figure 1c) when comparing drought-affected (0 ppm $\mathrm{SiO}_{2} \mathrm{NPs}, \mathrm{SM} \mathrm{30} \%$ ) and control plants (SM 80\%). Comparing the effects of $0 \mathrm{ppm}$ and $12.5 \mathrm{ppm} \mathrm{SiO} \mathrm{S}_{2}$ on plant root/shoot ratio when watered or sprayed in drought treatment, no statistically significant difference was found. However, a statistically significant effect on root/shoot ratio was found by watering or spraying peas at a concentration of $25 \mathrm{ppm} \mathrm{SiO}_{2}$ compared to $\mathrm{SiO}_{2} \mathrm{NPs}$ untreated plants $(0 \mathrm{ppm})$ in drought-affected peas. Meanwhile, the root/shoot ratio of peas grown under drought did not differ significantly from control plants when were watered or sprayed with $50 \mathrm{ppm}$ $\mathrm{SiO}_{2} \mathrm{NPs}$.

\subsection{Influence of Drought Stress and $\mathrm{SiO}_{2} \mathrm{NPs}$ on Lipid Peroxidation and Hydrogen Peroxide}

The malondialdehyde (MDA) and hydrogen peroxide $\left(\mathrm{H}_{2} \mathrm{O}_{2}\right)$ content in peas increased significantly under drought stress $(0 \mathrm{ppm} \mathrm{SiO} 2 \mathrm{NPs}, \mathrm{SM} 30 \%)$ compared to control plants, i.e., 24 and $132 \%$, respectively (Figure $2 a, b)$.

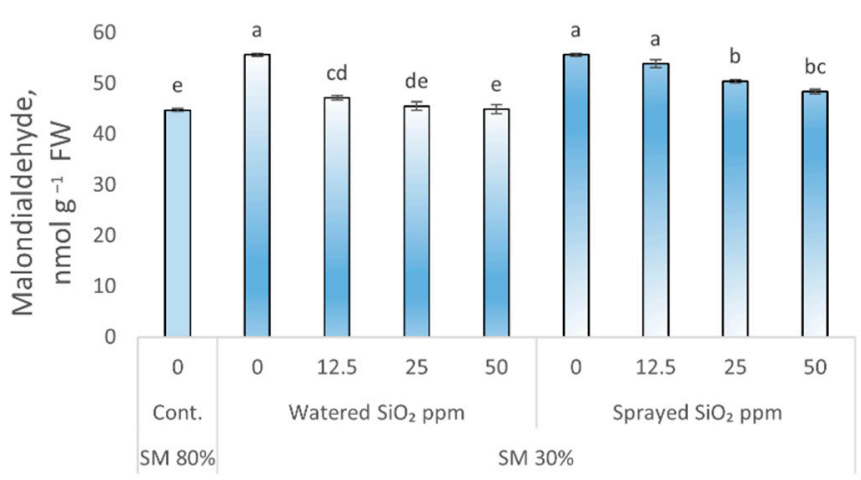

(a)

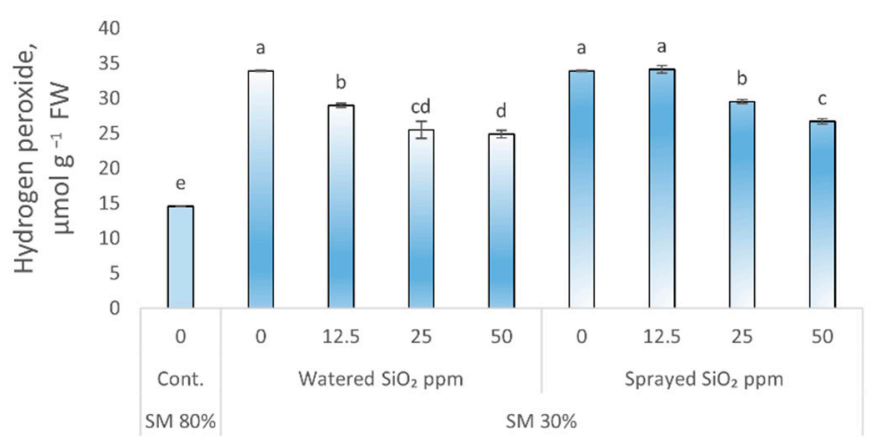

(b)

Figure 2. Influence of drought stress and $\mathrm{SiO}_{2} \mathrm{NPs}(0 ; 12.5 ; 25 ;$ and $50 \mathrm{ppm})$ on malondialdehyde content (MDA), (a); hydrogen peroxide $\left(\mathrm{H}_{2} \mathrm{O}_{2}\right)$, (b) in P. sativum L. Cont.-control plants, substrate moisture (SM) 80\%; drought stress-SM 30\%. Values are mean \pm SE of three replicates and different letters are differed significantly by Tukey HSD Test $(p<0.001)$.

All applied $\mathrm{SiO}_{2} \mathrm{NPs}$ concentrations significantly reduced the content of MDA and $\mathrm{H}_{2} \mathrm{O}_{2}$ in peas compared to NPs-untreated (0 $\mathrm{ppm} \mathrm{SiO}_{2} \mathrm{NP}, \mathrm{SM} 30 \%$ ) plants as they were 
watered with $\mathrm{SiO}_{2} \mathrm{NPs}$. However, no statistical reliability was found when comparing MDA levels in plants watered with 25 and $50 \mathrm{ppm} \mathrm{SiO}_{2} \mathrm{NPs}_{\text {concentrations with control }}$ plants. Spraying peas with $\mathrm{SiO}_{2} \mathrm{NPs}$ resulted in a statistically significant reduction in MDA and $\mathrm{H}_{2} \mathrm{O}_{2}$ content at $25 \mathrm{ppm}$ ( 9 and 13\%, respectively) and $50 \mathrm{ppm}$ (13 and 21\%, respectively) $\mathrm{SiO}_{2} \mathrm{NPs}$ concentrations compared to NP-untreated plants under drought stress ( 0 ppm $\mathrm{SiO}_{2} \mathrm{NPs}, \mathrm{SM} 30 \%$ ), but still exceeded the level of control plants.

\subsection{Effect of Drought Stress and $\mathrm{SiO}_{2} \mathrm{NPs}$ on Antioxidant Activity}

The total phenolic compounds (TPC), DPPH and ABTS free radical scavenging activity, and FRAP antioxidant power in pea leaves were significantly reduced by drought stress (0 ppm $\left.\mathrm{SiO}_{2} \mathrm{NPs}, \mathrm{SM} 30 \%\right)(24,16,39$, and $17 \%$, respectively) compared to control plants (Figure 3). There were no statistically significant changes in TPC and DPPH value between control plants and peas sprayed with $50 \mathrm{ppm} \mathrm{SiO}_{2} \mathrm{NPs}$. Moreover, there was no significant effect on FRAP value when peas were watered with $25,50 \mathrm{ppm}$ and sprayed with $50 \mathrm{ppm}$ $\mathrm{SiO}_{2} \mathrm{NPs}$ as compared to control plants. ABTS free radical scavenging activity in peas sprayed with 12.5 and $25 \mathrm{ppm} 50 \mathrm{ppm} \mathrm{SiO}_{2} \mathrm{NPs}$ under drought stress was significantly reduced compared to control plants. However, a statistically significant increase in ABTS value was found in plants watered with $12.5,25$, and $50 \mathrm{ppm} \mathrm{SiO}_{2} \mathrm{NPs}$ under drought exposure.

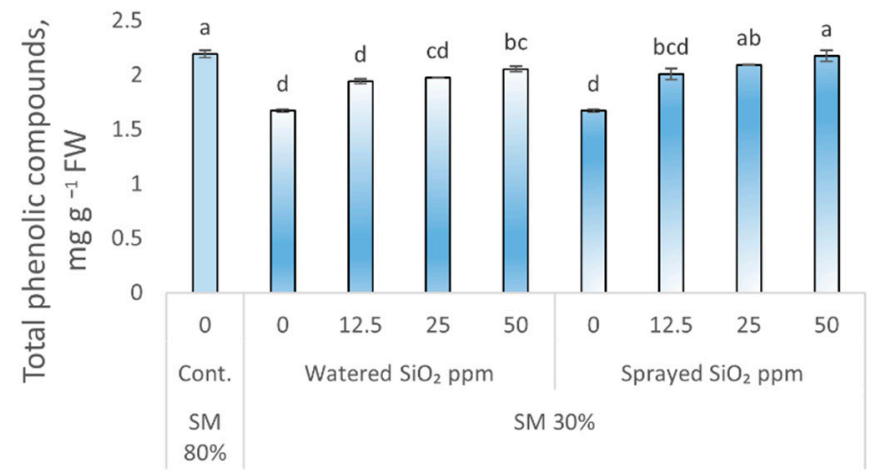

(a)

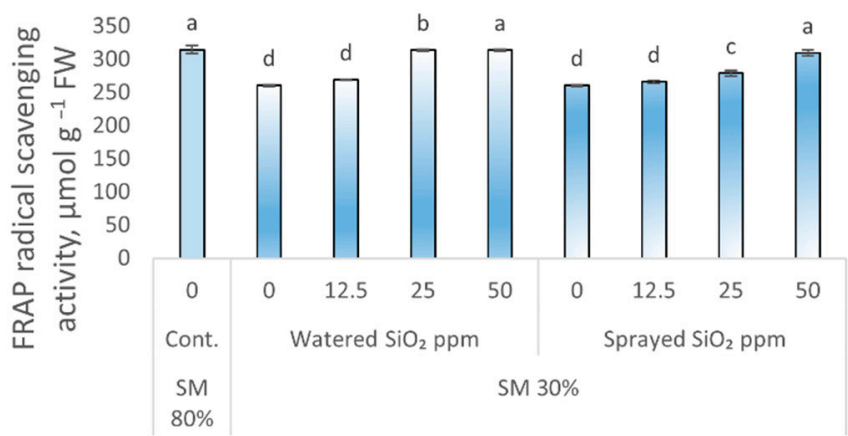

(c)

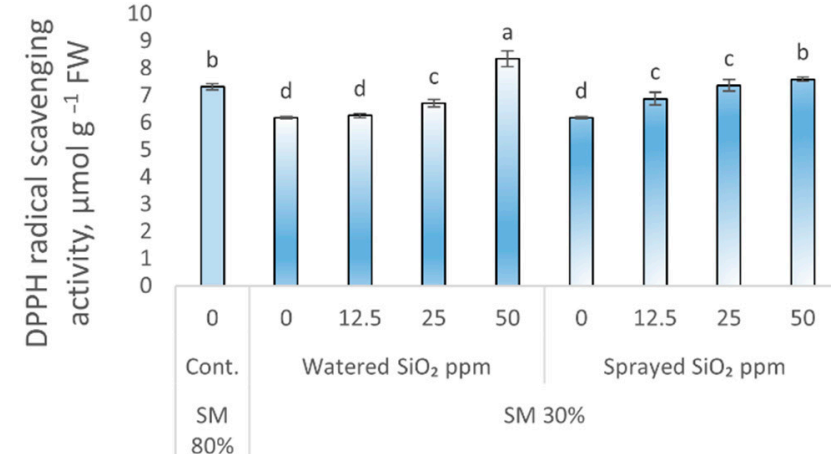

(b)

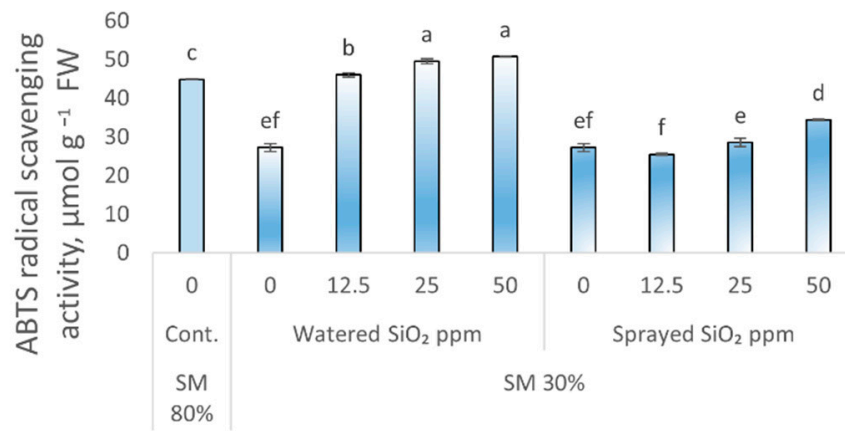

(d)

Figure 3. Influence of drought stress and $\mathrm{SiO}_{2} \mathrm{NPs}(0 ; 12.5 ; 25$; and $50 \mathrm{ppm})$ on total phenolic compounds (a); DPPH radical scavenging activity (b); FRAP radical scavenging activity (c); ABTS radical scavenging activity (d) in P. sativum L. Cont.-Control plants, substrate moisture (SM) $80 \%$; drought stress-SM 30\%. Values are mean \pm SE of three replicates and different letters are differed significantly by Tukey HSD Test $(p<0.001)$.

\subsection{Effect of Drought Stress and $\mathrm{SiO}_{2} \mathrm{NPS}$ on Antioxidant Enzymes Activities}

Superoxide dismutase (SOD), catalase (CAT), ascorbate peroxidase (APX), and glutathione reductase (GR) activity increased in peas affected by drought compared with control plants (Figure 4). The most active antioxidants were found when plants were wa- 
tered with $\mathrm{SiO}_{2} \mathrm{NPs}$ suspensions. SOD activity was most increased by watering plants with $25 \mathrm{ppm}(95 \%)$ and $50 \mathrm{ppm}(103 \%)$ or by spraying with $50 \mathrm{ppm}(82 \%) \mathrm{SiO}_{2} \mathrm{NPs}$ compared with control plants (Figure 4a). Increased CAT activity was observed in both watered and sprayed plants at all applied concentrations but was most pronounced when peas were exposed to $50 \mathrm{ppm} \mathrm{SiO}_{2}$ NPs suspension (Figure $4 \mathrm{~b}$ ). The activity of the APX enzyme in peas was also increased in drought conditions (Figure 4c) when plants were watered at $0,12.5,25$, and 50 ppm NPs concentrations, APX activity increased by 158, 244, 288, and $309 \%$ respectively, compared to control plants. As with all enzymes tested, GR activity in peas also increased under drought conditions (Figure $4 \mathrm{~d}$ ) when plants were watered at 0 , $12.5,25$, and $50 \mathrm{ppm} \mathrm{SiO} 2 \mathrm{NPs}$ suspension, GR activity increased by $39,41,69$, and $178 \%$, respectively, compared to control plants.

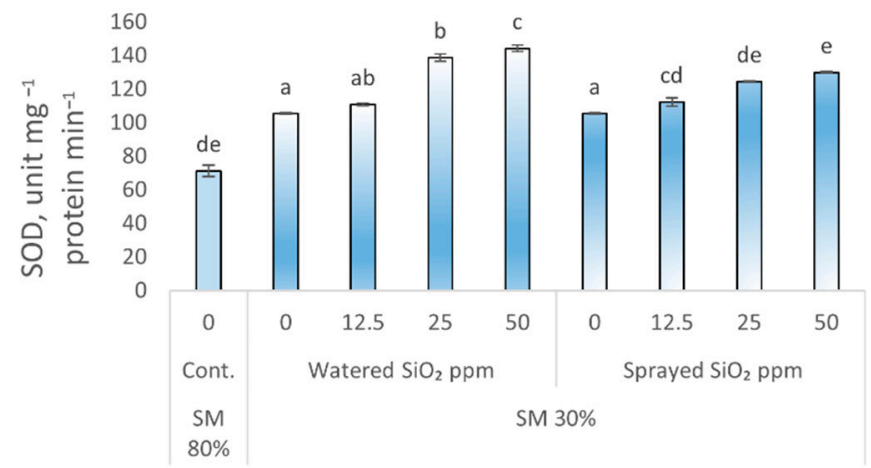

(a)

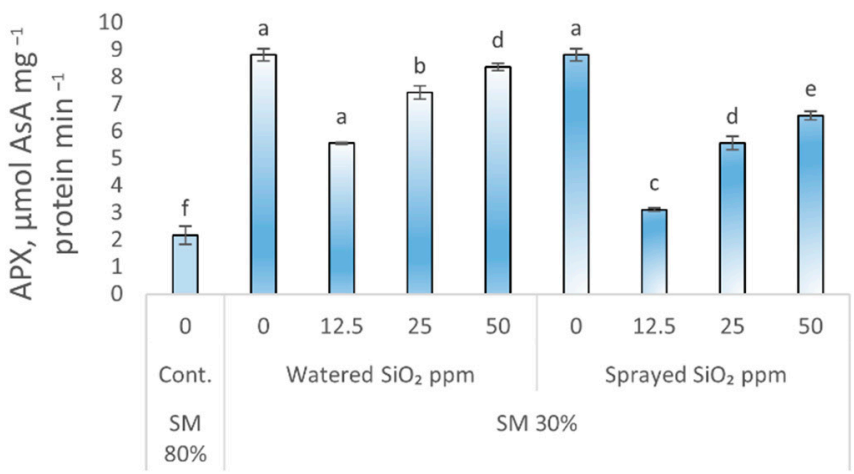

(c)

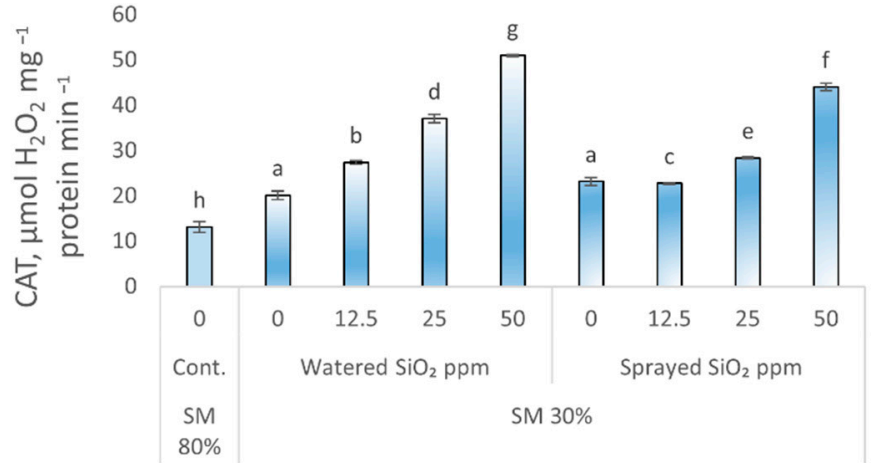

(b)

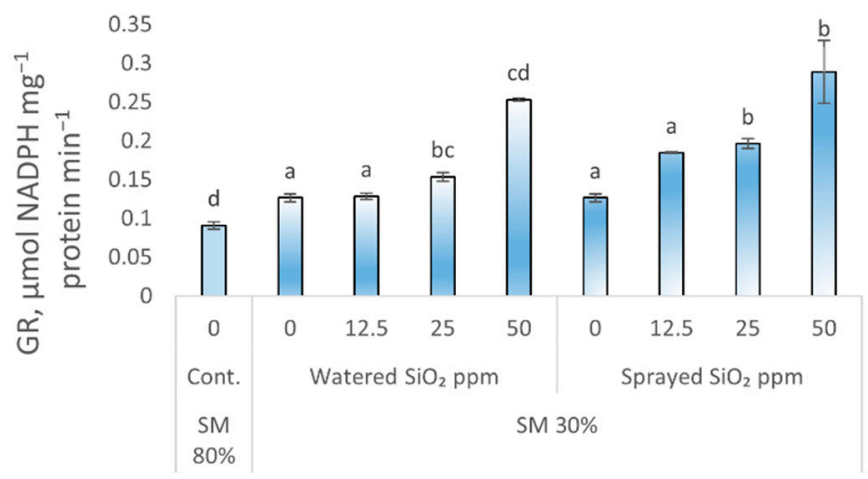

(d)

Figure 4. Response of (a), superoxide dismutase (SOD); (b), catalase (CAT); (c), ascorbate peroxidase (APX); (d), glutathione reductase (GR) activity to drought stress and $\mathrm{SiO}_{2} \mathrm{NPs}(0 ; 12.5 ; 25$; and 50 ppm) in P. sativum L. Cont.—control plants, substrate moisture (SM) 80\%; drought stress-SM 30\%. Values are mean $\pm \mathrm{SE}$ of three replicates and different letters are differed significantly by Tukey HSD Test $(p<0.001)$.

\section{Discussion}

This study elucidated the effects of $\mathrm{SiO}_{2}$ NPs on drought stress in pea plants based on NP concentration and different applications (leaf application and root irrigation) to explain the main physiological, non-enzymatic, and enzymatic antioxidant defense mechanisms. The results of this study showed that $\mathrm{SiO}_{2} \mathrm{NPs}$ can alleviate drought-induced stress in plants. The above-presented research data indicate that the studied defense mechanisms significantly varied in $\mathrm{SiO}_{2}$ NPs non-treated and treated pea plants under drought stress.

\subsection{Effects of Different Applications and Concentration of NPS}

Several factors are responsible for the transformation and uptake of NPs in plants: physicochemical properties of NP itself, size, surface charge, concentration in the suspen- 
sion, potential interaction with plants, and plant physiology. Dissolved bulk silicon (Si) is known to be absorbed by plants in the form of mono-silicic acid $\left(\mathrm{Si}(\mathrm{OH})_{4}\right)$ and ultimately polymerizes with the loss of water molecules to form hydrated silica $\left(\mathrm{SiO}_{2} \cdot \mathrm{nH}_{2} \mathrm{O}\right)$ [35]. In plants with a high capacity for metalloid accumulation, it is assisted by one of aquaporin group MIP [36] —Si influx transporters (SiT1 and SiT2) and efflux transporters (SiT6) located in the main and lateral roots, responsible for the transport of Si from the cortical cells to the xylem [35-38]. The researchers found that pea plants tend to the silicification process using Si transporters [39]. However, NPs can have different properties than their bulk materials [40]. Plants can be affected by NPs in two ways, sprayed through shoots and watered through roots. Spraying-exposure through the leaves can form an additional layer on the leaves [17] to protect plants from increased transpiration and disease [41], but can also allow some NPs to penetrate through the wax layer and diffuse directly into the plant (limited to pore size 5-20 nm) [42]. Considering the composition of the cell wall, which has hydrophobic and hydrophilic components and unequal distribution of fixed negative charges (cellulose fibers and lignin surface potential are -15 and $-45 \mathrm{mV}$, respectively) $[9,43]$, it is noticeable that negatively charged plant cell walls act as an ion exchange surface that potentially promotes the penetration of cationic NPs rather than anionic ones. Considering the effects of irrigation when NPs are reached through the soil, it should be noted that the soil particles are usually negatively charged, and NPs with a higher negative charge, are more agile in such soil [44]. On the contrary, positively charged NPs easily attract negatively charged soil surface particles. In general, NPs mobility decreases as the average soil grain size decreases. The clay content of the soil can act as an anionic adjuvant to prevent NPs accumulation and increase their mobility [45]. Zeta potential measurement is a technique for determining the surface charge in a colloidal solution [46]. NPs with a zeta potential of -10 to $+10 \mathrm{mV}$ are approximately neutral, and NPs with a zeta potential greater than $+30 \mathrm{mV}$ or less than $-30 \mathrm{mV}$ are considered to be strongly cationic and anionic, respectively [47]. The zeta potential of the plasma membrane of various plants can vary from 20 to $-39 \mathrm{mV}$, but the zeta potential of the plasma membrane of pea has not been studied, making it difficult to estimate [48]. In future studies, it would be valuable to evaluate the zeta potential of the pea leaf plasma membrane when grown under normal and drought conditions. However, in our results, the zeta potential of the $\mathrm{SiO}_{2}$ suspension in distilled water was -20 meaning anion (Table 1). There is another scientific article describing that the application of $10 \mathrm{~g} \mathrm{~kg}^{-1} \mathrm{SiO}_{2} \mathrm{NPs}$ with a zeta potential of $-40 \mathrm{mV}$ through the soil had a positive effect on photosynthesis, yield quality, and increased productivity of maize plants [49]. Moreover, the researchers [50] found that negatively charged Au NPs accumulate less on the root surface but move most efficiently through the root epidermis to plant shoots, especially in rice and ryegrass.

The effect of NPs on plants is highly dependent on their concentration. In this study, the most effective concentration against drought-induced effects in peas was spraying and watering with 50 ppm $\mathrm{SiO}_{2}$ NPs. The researchers found that spraying strawberries with 125 ppm $\mathrm{SiO}_{2}$ NPs increased their resistance to drought [14]. Using concentrations of 100, 200, 300, and 400 ppm $\mathrm{SiO}_{2}$ NPs, a statistically significant effect was found for common bean germination [51]. Other researchers used Si NPs as leaf sprays at concentrations of $0,5,10$, 20, 30 ppm and found that the Cd-induced negative growth rates of rice were significantly reduced [18]. Previous comparative studies showed that approximately 140 ppm Si NPs were effective in reducing Cr (VI) toxicity in pea (Pisum sativum) [20], arsenate toxicity in maize (Zea mays) [13], and UV-B stress in wheat (Triticum aestivum) [17]. In another experiment with cucumbers [52], $\mathrm{SiO}_{2}$ NPs concentrations at 100, 200, 300, 400 ppm were used, of which the concentration at 200 ppm caused the greatest positive effect in plants. In addition, researchers [19] sprayed potatoes with $\mathrm{SiO}_{2} \mathrm{NPs}$ concluded that a concentration of 50 ppm had a positive, but a concentration of $100 \mathrm{ppm}$ had a statistically significant negative effect on plants. In contrast, the opposite, negative effect was found for $\mathrm{SiO}_{2} \mathrm{NPs}$ at concentrations 10, 100, 500, and 2000 ppm on Bt-transgenic cotton height and weight [5]. 
These results confirm that the effects of NPs depend not only on the NPs and applied concentration, but also on their interaction with the plant species.

\subsection{Influence of Drought Stress and $\mathrm{SiO}_{2} \mathrm{NPs}$ on Oxidative Stress Markers and Antioxidant Enzymes Activities in Peas}

The effects of appropriately selected and studied doses of NPs on plants and the soil ecosystem could address the food insecurity caused by climate change, which is challenging agriculture. In our research, the deficiency of water in soil caused oxidative stress resulting in increased malondialdehyde (MDA) and hydrogen peroxide $\left(\mathrm{H}_{2} \mathrm{O}_{2}\right)$ levels in pea plants (Figure 2a,b), but watering or spraying plants with $\mathrm{SiO}_{2} \mathrm{NPs}$ reduced the harmful effects of drought stress. Drought stress increased the activity of antioxidant enzymes, including CAT, APX, SOD, and GR (Figure 4), in the leaves of pea plants compared to control plants grown with insufficient moisture supply, while exposure to $\mathrm{SiO}_{2} \mathrm{NPs}$ further strengthened the activity of these enzymes. Previous studies $[53,54]$ have shown that severe drought causes oxidative stress due to the accumulation of reactive oxidative species (ROS) in plant cells, including superoxide radicals $\left(\mathrm{O}_{2}{ }^{\bullet-}\right)$, alkoxy radicals $(\mathrm{RO} \bullet)$ and hydroxyl radicals $(\mathrm{OH} \bullet)$, hydrogen peroxide $\left(\mathrm{H}_{2} \mathrm{O}_{2}\right)$, and singlet oxygen $\left({ }^{1} \mathrm{O}_{2}\right)$. However, plants have adapted to eliminate excessive oxidative stress agents using antioxidant defense systems consisting of enzymatic (SOD, CAT, GSH, etc.) and non-enzymatic (ascorbic acid, phenolic compounds, carotenoids, etc.) antioxidants $[53,55,56]$. As the amount of oxidative stress products in plants increases, the antioxidant system activates, for example, superoxide dismutase converts the superoxide radical to hydrogen peroxide (which is less harmful to the plant) then the peroxide decomposes into the water using antioxidants such as CAT, APX, GPX (using different reaction catalysts) [54]. As can be seen in Figure 3, the application of $\mathrm{SiO}_{2} \mathrm{NPs}$ tends to stimulate a non-enzymatic antioxidant response by increasing TPC, $\mathrm{DPPH}, \mathrm{FRAP}$, and most strongly ABTS radical scavenging activity in pea plants exposed to drought stress. The ABTS [57] and FRAP methods show a greater correlation with non-enzymatic hydrophilic antioxidants such as $\alpha$-tocopherols, flavonoids, and ascorbic acid, and the DPPH method showed a higher correlation with lipophilic antioxidants such as carotenoids [25]. According to the results of ABTS, FRAP, and TPC, it can be stated that peas contain more hydrophilic antioxidants than lipophilic in terms of DPPH results.

In general, increased levels of MDA, $\mathrm{H}_{2} \mathrm{O}_{2}$, and other antioxidant enzymes have been reported in various plant species under drought stress $[14,56,58,59]$. In this study, a significant increase in MDA and $\mathrm{H}_{2} \mathrm{O}_{2}$ in pea leaves (Figure 2) in response to water deficiency caused strong oxidative stress resulting in retarded plant growth, decreased RWC, SLA, and increased root/shoot ratio (Figure 1), indicating that pea plants in the lack of soil moisture encourage root growth. MDA can generally be described as a process in which oxidants, such as free radicals, attack lipids having a carbon-carbon double bond(s), especially polyunsaturated fatty acids (PUFAs) [60]. According to the results obtained by other researchers [61], PUFAs in peas are less than in other plants of the Legumes family. Besides, the amount of PUFAs had a positive correlation with DPPH antioxidants, which in pea plants also had lower activity compared to ABTS (Figure 3b,d). In this study, a very strong increase was found in the activity of enzymatic antioxidants such as SOD, CAT, APX, and GR (Figure 4) when pea plants were watered or sprayed with $\mathrm{SiO}_{2} \mathrm{NPs}$ especially at $50 \mathrm{ppm}$ (enzyme activity increased with increasing $\mathrm{SiO}_{2} \mathrm{NPs}_{\text {concentration). }}$ In response to water deficit, due to stomatal closure, low $\mathrm{CO}_{2}$ availability, and limited fixation, oxygen saturation of ribulose 1,5-bisphosphate (RuBP) is preferred that enhances photorespiration [59] leading to more than $70 \%$ of the $\mathrm{H}_{2} \mathrm{O}_{2}$ generation in plants. Besides, $\mathrm{H}_{2} \mathrm{O}_{2}$ is formed in the plant when the enzyme SOD performs the monovalent reduction and protonation of the superoxide radical [53]. In this study, significant activation of SOD along with other enzymatic antioxidants activity was observed in pea plants under water deficit. We suppose that, due to this, a significant decrease in $\mathrm{H}_{2} \mathrm{O}_{2}$ (Figure $2 \mathrm{~b}$ ) was observed in peas as plants were watered with $\mathrm{SiO}_{2} \mathrm{NPs}$ in the presence of a water deficit. As mentioned above, $\mathrm{SiO}_{2} \mathrm{NPs}$ may enter the pea plant through special channels in the roots, then move 
in a symplastic pathway in the plant and enter the cell cytosol containing most of the enzymatic antioxidants and thus affect plant with abnormal particle surface area, size, and charge. This explains the more efficient watering of $\mathrm{SiO}_{2} \mathrm{NPs}$ than foliar application to plants.

$\mathrm{SiO}_{2} \mathrm{NPs}$ have a very strong relationship with water content in plants; there are just a few published scientific articles specifically on the effects of drought. For instance, in strawberries, spraying with Si NPs during drought stress increased the activity of CAT, APX, SOD, and GR enzymes and decreased the content of MDA and $\mathrm{H}_{2} \mathrm{O}_{2}$ [14]. The relationship of Si NPs and other abiotic factors such as salinity, exposure to heavy metals, and UV radiation to plants were also explored by researchers. For example, when spraying with 50 ppm $\mathrm{SiO}_{2}$ NPs suspension in salinity-treated potato seedlings, the researchers found [19] that enzymatic antioxidants such as GPX and SOD were more active compared to potatoes not sprayed with $\mathrm{SiO}_{2}$ suspension. The negative effects of $\mathrm{Cr}$ (VI) were found in peas with increased $\mathrm{H}_{2} \mathrm{O}_{2}$ and MDA concentrations but spraying them with Si NPs resulted in a clear decrease in oxidative stress biomarkers and activated enzymatic antioxidants such as SOD, CAT, GR, APX [20]. Moreover, when common beans were sprayed with 30 ppm $\mathrm{SiO}_{2} \mathrm{NPs}_{\text {, }}$ a statistically positive increase in the activity of antioxidant enzymes and a decrease in the concentration of MDA and $\mathrm{H}_{2} \mathrm{O}_{2}$ were observed under $\mathrm{Cd}$ stress [18]. Similar results were obtained when researchers studied [62] the effects of $\mathrm{Cd}-, \mathrm{Pb}$-affected rice and foliar application of $\mathrm{SiO}_{2}$ NPs, the sprayed plants with 20 ppm $\mathrm{SiO}_{2}$ NPs accumulated less heavy metals and produced the highest yields. The $\mathrm{SiO}_{2} \mathrm{NPs}$ have been shown [17] to protect wheat seedlings from UV-B stress by stimulating the antioxidant defense system and reducing the negative effects of UV-B stress, such as low fresh weight, chlorophyll content, and tissue damage. Researchers noted that as nitric oxide levels reached a peak after exposure to UV-B and Si NPs, the protection arises from modulating NO levels.

\subsection{Effects of Drought Stress and $\mathrm{SiO}_{2} \mathrm{NPs}$ on Peas Specific Leaf Area, Relative Water Content, and Root/Shoot Ratio}

In plants, decreased growth parameters may be due to decreased relative water content (RWC) and corresponding cell contraction, decreased meristematic cell division, decreased leaf growth, accelerated aging, blocked leaf production, and leaf fall. Water stress can also directly affect the biochemical processes involved in photosynthesis and indirectly reduce the uptake of carbon dioxide into the stoma, which closes during drought. In this study, relative water content (RWC) (Figure 1a) and specific leaf area (SLA) (Figure 1b) of pea plants significantly decreased during drought stress, but watering or spraying with a suspension containing $\mathrm{SiO}_{2}$ NPs increased their contents. Plant membranes are the first place in the cell which are influenced under stress conditions and the ability of plants to protect the integrity of membranes under drought stress determines the tolerance of the plants to drought stress [63]. Under drought stress, the water potential of soil decreases, and plants prevent transpiration phenomenon using different mechanisms such as closing stomata, increasing stomatal resistance, and decreasing stomatal conductivity. Scientists showed that the improving effect of Si on the hydration status of plants may help to reduce leaf and stem transpiration or the deposition of phytolith under epidermal cells, resulting in a decreased waste of water from cuticle layers [64]. According to that concentration of 50 ppm, $\mathrm{SiO}_{2}$ NPs play an important role in increasing RWC in pea plants (Figure 1a) under stressful conditions. Similar RWC results were found in drought-affected strawberries [14], wheat [58], and cucumber [52]. The researchers also found a statistically positive increase in rice height, shoot, and root weight under $\mathrm{Cd}$ stress and spraying of $\mathrm{SiO}_{2} \mathrm{NPs}$ [18]. A study by other scientists has shown that drought stress has negatively affected wheat growth rates and yields [58], but the use of $\mathrm{SiO}_{2} \mathrm{NPs}$, especially through soil application at 30 and $60 \mathrm{ppm}$, reduced the negative effects of drought stress by reducing transpiration, improving the rate of photosynthesis, increasing chlorophyll content and RWC. Moreover, similar results were found in peas [20], maize [13], and wheat [17] affected by various stressors, 
with a statistically positive increase in fresh leaf and root biomass, also leaf area using Si NPs.

Previous studies [65] indicate that the root/shoot ratio increases with drought, as plants tend to grow roots and absorb more water over a larger root surface, resulting in reduced shoot growth. This trend was also observed in our study, with a significant increase in root/shoot ratio in drought-affected peas (Figure 1c), but the application of $\mathrm{SiO}_{2} \mathrm{NPs}$ at $50 \mathrm{ppm}$ reduced the negative effects of drought stress on the root/shoot ratio. These results confirm that the application of $\mathrm{SiO}_{2} \mathrm{NPs}$ can strongly affect plant development under drought exposure.

\section{Conclusions}

In conclusion, watering or foliar spraying solutions containing $50 \mathrm{ppm} \mathrm{SiO}_{2} \mathrm{NPs}$ on pea plants is an efficient way to improve their resistance to drought stress. Favorable effects of $\mathrm{SiO}_{2} \mathrm{NPs}$ on pea growth efficiency under drought conditions have been attributed to the activation of the enzymatic and non-enzymatic antioxidative system to eliminate ROS and enhance relative water content, specific leaf area, and decreased root/shoot level. Based on the results obtained, the use of $\mathrm{SiO}_{2} \mathrm{NPs}$ is recommended for managing the drought stress in pea plants and even in other agricultural plants.

Author Contributions: Conceptualization, R.S., A.B., G.S. and J.M.; methodology, R.S., A.B., L.R., G.S., M.U. and J.M.; validation, A.B., G.S., M.U. and J.M.; formal analysis, R.S.; investigation, R.S.; resources, L.R., G.S. and J.M.; writing-original draft preparation, R.S.; writing-review and editing, A.B., L.R., G.S. and J.M.; visualization, R.S.; supervision, J.M. All authors have read and agreed to the published version of the manuscript.

Funding: This research received no external funding.

Acknowledgments: R.S. is thankful to the Lithuanian Research Centre for Agriculture and Forestry for the opportunity to work with nanoparticles and for donated green pea "Respect" seeds. The authors are also grateful to Joana Bendoraitienè from the Kaunas University of Technology for measuring the size and zeta potential of nanoparticle suspension.

Conflicts of Interest: The authors declare no conflict of interest.

\section{References}

1. Spinoni, J.; Barbosa, P.; Bucchignani, E.; Cassano, J.; Cavazos, T.; Christensen, H.J.; Christensen, B.O.; Coppola, E.; Evans, J.; Geyer, B.; et al. Future global meteorological drought hot spots: A study based on CORDEX data. J. Clim. 2020, 33, 3635-3661. [CrossRef]

2. Chhipa, H.; Joshi, P. Nanofertilisers, Nanopesticides and Nanosensors in Agriculture. Sustain. Agric. Rev. 2016, $20,247-282$.

3. Zulfigar, F.; Navarro, M.; Ashraf, M.; Akram, A.N.; Munne-Bosch, S. Nanofertilizer use for sustainable agriculture: Advantages and limitations. Plant Sci. 2019, 289, 110270. [CrossRef]

4. Gomez, A.; Narayan, M.; Zhao, L.; Jia, X.; Bernal, R.; Lopez-Moreno, L.M.; Peralta-Videa, J. Effects of nano-enabled agricultural strategies on food quality: Current knowledge and future research needs. J. Hazard. Mater. 2020, 401, 12391-12398. [CrossRef]

5. Rui, Y.; Gui, X.; Li, X.; Liu, S.; Han, Y. Uptake, transport, distribution and bio-effects of $\mathrm{SiO}_{2}$ nanoparticles in Bt-transgenic cotton. J. Nanobiotechnol. 2014, 12, 1-15. [CrossRef]

6. Tarafdar, J.C.; Xiong, Y.; Wang, W.N.; Quinl, D.; Biswas, P. Standardization of size, shape and concentration of nanoparticle for plant application. Appl. Biol. Res. 2012, 14, 138-144.

7. Mittal, D.; Kaur, G.; Singh, P.; Yadav, K.; Ali, S.A. Nanoparticle-based sustainable agriculture and food science: Recent advances and future outlook. Front. Nanotechnol. 2020, 2, 10. [CrossRef]

8. Nadmint, P.P.; Dong, Y.D.; Sayer, C.; Hay, P.; Rookes, J.E.; Boyd, B.J.; Cahill, D.M. Nanostructured liquid crystalline particles as an alternative delivery vehicle for plant agrochemicals. ACS Appl. Mater. Interfaces 2013, 5, 1818-1826. [CrossRef] [PubMed]

9. Santiago, M.; Pagay, V.; Stroock, D.A. Impact of electroviscosity on the hydraulic conductance of the bordered pit membrane: A theoretical investigation. Plant Physiol. 2013, 163, 999-1011. [CrossRef]

10. Meychik, R.N.; Nikolaeva, I.J.; Yermakov, P.I. Ion exchange properties of the root cell walls isolated from the halophyte plants (Suaeda altissima L.) grown under conditions of different salinity. Plant Soil. 2005, 277, 163-174. [CrossRef]

11. Sun, D.; Hussain, H.I.; Yi, Z.; Siegele, R.; Cresswell, T.; Kong, L.; Cahill, D.M. Uptake and cellular distribution, in four plant species, of fluorescently labeled mesoporous silica nanoparticles. Plant Cell Rep. 2014, 33, 1389-1402. [CrossRef]

12. Luyckx, M.; Hausman, J.F.; Guerriero, G.; Lutts, S. Silicon and plants: Current knowledge and technological perspectives. Front. Plant Sci. 2017, 8, 411. [CrossRef] 
13. Tripathi, D.K.; Singh, S.; Singh, V.P.; Prasad, S.M.; Chauhan, D.K.; Dubey, N.K. Silicon nanoparticles more efficiently alleviate arsenate toxicity than silicon in maize cultivar and hybrid differing in arsenate tolerance. Front. Environ. Sci. $2016,4,46$. [CrossRef]

14. Zahedi, S.M.; Moharrami, F.; Sarikhani, S.; Padervand, M. Selenium and silica nanostructure-based recovery of strawberry plants subjected to drought stress. Sci. Rep. 2020, 10, 17672. [CrossRef]

15. Shabbaj, I.I.; Madany, M.M.Y.; Tammar, A.; Balkhyour, M.A.; AbdElgawad, H. Silicon Dioxide Nanoparticles Orchestrate Carbon and Nitrogen Metabolism in Pea Seedlings to Cope with Broomrape Infection. Environ. Sci. Nano 2021, 8, 1960-1977. [CrossRef]

16. Tantawy, S.A.; Salama, M.Y.A.; El-Nemr, A.M.; Abdel-Mawgoud, R.A.M. Nano silicon application improves salinity tolerance of sweet pepper plants. Int. J. Chemtech Res. 2015, 8, 11-17.

17. Tripathi, D.K.; Singh, S.; Singh, V.P.; Prasad, S.M.; Dubey, N.K.; Chauhan, D.K. Silicon nanoparticles more effectively alleviated UV-B stress than silicon in wheat (Triticum aestivum) seedlings. Plant Physiol. Biochem. 2017, 110, 70-81. [CrossRef] [PubMed]

18. Rizwan, M.; Ali, S.; Rehman, Z.M.; Malik, S.; Adrees, M.; Qayyum, F.M.; Alamri, A.S.; Alyemeni, N.M.; Ahmad, P. Effect of foliar applications of silicon and titanium dioxide nanoparticles on growth, oxidative stress, and cadmium accumulation by rice (Oryza sativa). Acta Physiol. Plant 2019, 41, 1-12. [CrossRef]

19. Gowayed, H.M.; Al-Zahrani, S.H.; Metwali, M.E. Improving the salinity tolerance in potato (Solanum tuberosum) by exogenous application of silicon dioxide nanoparticles. Int. J. Agric. Biol. 2017, 19, 183-192.

20. Tripathi, D.K.; Singh, V.P.; Prasad, S.M.; Chauhan, D.K.; Dubey, N.K. Silicon nanoparticles (SiNp) alleviate chromium (VI) phytotoxicity in Pisum sativum (L.) seedlings. Plant Physiol. Biochem. 2015, 96, 189-198. [CrossRef]

21. Attia, A.E.; Elhawat, N. Combined foliar and soil application of silica nanoparticles enhances the growth, flowering period and flower characteristics of marigold (Tagetes erecta L.). Sci. Hortic. 2021, 282, 110015. [CrossRef]

22. Meier, U. Growth Stages of Mono- and Dicotyledonous Plants: BBCH-Monograph Entwicklungsstadien Mono- und Dikotyler Pflanzen; Biologische Bundesanstalt für Land- und Forstwirtschaft in Berlin und Braunschweig, Ed.; Blackwell Wissenschafts-Verlag: Berlin, Germany; Wien, Austria, 1997; ISBN 9783826331527.

23. Baris, D.H.; Weatherley, E.P. A re-examination of the relative turgidity technique for estimating water deficits in leaves. Aust. J. Biol. Sci. 1962, 24, 519-570. [CrossRef]

24. Ainsworth, E.A.; Gillespie, K.M. Estimation of Total Phenolic Content and Other Oxidation Substrates in Plant Tissues Using Folin-Ciocalteu Reagent. Nat. Protoc. 2007, 2, 875-877. [CrossRef] [PubMed]

25. Re, R.; Pellegrini, N.R.; Proteggente, A.; Pannala, A.; Yang, M.; Rice-Evans, C. Antioxidant activity applying an improved ABTS radical cation decolorization assay. Free Radic. Biol. Med. 1999, 26, 1231-1237. [CrossRef]

26. Sharma, P.O.; Bhat, K.T. DPPH antioxidant assay revisited. Food Chem. 2009, 113, 1202-1205. [CrossRef]

27. Benzie, I.F.; Strain, J.J. The ferric reducing ability of plasma (FRAP) as a aeasure of "Antioxidant power": The FRAP assay. Anal. Biochem. 1996, 239, 70-76. [CrossRef]

28. Velikova, V.; Yordanov, I.; Edreva, A. Oxidative stress and some antioxidant system in acid rain treated bean plants: Protective role of exogenous polyammines. Plant Sci. 2000, 151, 59-66. [CrossRef]

29. Heath, R.L.; Packer, L. Photoperoxidation in isolated chloroplasts. I. Kinetics and stoichiometry of fatty acid peroxidation. Arch Biochem. Biophys. 1968, 125, 189-198. [CrossRef]

30. Bradford, M.M. A rapid and sensitive method for the quantification of microgram quantities of protein utilizing the principle of protein-dye binding. Anal. Biochem. 1976, 72, 248-254. [CrossRef]

31. Dhindsa, S.R.; Plumb-Dhindsa, P.; Thorpe, A.T. Leaf senescence: Correlated with increased levels of membrane permeability and lipid peroxidation and decreased levels of superoxide dismutase and catalase. J. Exp. Bot. 1981, 32, 93-101. [CrossRef]

32. Aebi, H. Catalase in vitro. Meth. Enzymol. 1984, 105, 121-126. [CrossRef]

33. Nakano, Y.; Asada, K. Hydrogen peroxide is scavenged by ascorbate-specific peroxidase in spinach chloroplasts. Plant Cell Physiol. 1981, 22, 867-880. [CrossRef]

34. Sofo, A.; Tuzio, C.A.; Dichio, B.; Xiloyannis, C. Influence of water deficit and rewatering on the components of the ascorbateglutathione cycle in four interspecific Prunus hybrids. Plant Sci. 2005, 169, 403-412. [CrossRef]

35. Kumar, S.; Soukup, M.; Elbaum, R. Silicification in grasses: Variation between different cell types. Front. Plant Sci. 2017, 8, 438. [CrossRef]

36. Maurel, C.; Boursiac, Y.; Luu, T.D.; Santoni, V.; Shahzad, Z.; Verdoucq, L. Aquaporins in plants. Physiol. Rev. 2015, 95, 1321-1358 [CrossRef]

37. Rao, G.B.; Susmitha, P. Silicon uptake, transportation and accumulation in rice. J. Pharmacogn. Phytochem. 2017, 6, $290-293$.

38. Guntzer, F.; Keller, C.; Meunier, D.J. Benefits of plant silicon for crops: A review. Agron. Sustain. Dev. 2012, 32, 201-213. [CrossRef]

39. Sangster, A.G.; Hodson, M.J.; Tubb, H.J. Silicon deposition in higher plants. In Studies in Plant Science; Datnoff, L.E., Snyder, G.H., Korndörfer, G.H., Eds.; Elsevier: Amsterdam, The Netherlands, 2001; Volume 8, pp. 85-113. [CrossRef]

40. Roduner, E. Size matters: Why nanomaterials are different. Chem. Soc. Rev. 2006, 35, 583-592. [CrossRef] [PubMed]

41. Siddiqui, M.H.; Al-Whaibi, M.H. Role of nano-SiO ${ }_{2}$ in germination of tomato (Lycopersicum esculentum seeds Mill.). Saudi J. Biol. Sci. 2014, 21, 13-17. [CrossRef]

42. Palocci, C.; Valletta, A.; Chronopoulou, L.; Donati, L.; Bramosanti, M.; Brasili, E.; Baldan, B.; Pasqua, G. Endocytic pathways involved in PLGA nanoparticle uptake by grapevine cells and role of cell wall and membrane in size selection. Plant Cell Rep. 2017, 36, 1917-1928. [CrossRef] 
43. Zeng, Y.; Himmel, M.E.; Ding, S.Y. Visualizing chemical functionality in plant cell walls. Biotechnol. Biofuels 2017, 10, 1-16. [CrossRef]

44. Darlington, T.K.; Neigh, M.A.; Spencer, T.M.; Guyen, T.O.; Oldenburg, S.J. Nanoparticle characteristics affecting environmental fate and transport through soil. Environ. Toxicol. Chem. 2009, 28, 1191-1199. [CrossRef] [PubMed]

45. Schrick, B.; Hydusky, W.B.; Blough, L.J.; Mallouk, E.T. Delivery vehicles for zerovalent metal nanoparticles in soil and groundwater. Chem. Mater. 2004, 16, 2187-2193. [CrossRef]

46. Kumar, A.; Dixit, K.C. Methods for Characterization of Nanoparticles. In Advances in Nanomedicine for the Delivery of Therapeutic Nucleic Acids; Nimesh, S., Chandra, R., Gupta, N., Eds.; Woodhead Publishing: Cambridge, UK, 2017; pp. 43-58. [CrossRef]

47. Clogston, J.D.; Patri, A.K. Zeta potential measurement. Methods Mol. Biol. 2011, 697, 63-70. [CrossRef]

48. Kinraide, T.B.; Wang, P. The surface charge density of plant cell membranes $(\sigma)$ : An attempt to resolve conflicting values for intrinsic $\sigma$. J. Exp. Bot. 2010, 61, 2507-2518. [CrossRef]

49. El-Naggar, M.E.; Abdelsalam, N.R.; Fouda, M.M.; Mackled, M.I.; Al-Jaddadi, M.A.; Ali, H.M.; Siddiqui, M.H.; Kandil, E.E. Soil application of nano silica on maize yield and its insecticidal activity against some stored insects after the post-harvest. Nanomaterials 2020, 10, 739. [CrossRef]

50. Zhu, J.Z.; Wang, H.; Yan, B.; Zheng, H.; Jiang, Y.; Mirand, R.O.; Rotello, M.V.; Xing, B.; Vachet, W.R. Effect of surface charge on the uptake and distribution of gold nanoparticles in four plant species. Environ. Sci. Technol. 2012, 46, 12391-12398. [CrossRef]

51. Alsaeedi, A.; El-Ramady, H.; Alshaal, A.T.; Almohsen, M. Enhancing seed germination and seedlings development of common bean (Phaseolus vulgaris) by $\mathrm{SiO}_{2}$ nanoparticles. Egypt. J. Soil Sci. 2017, 54, 407-415.

52. Alsaeedi, A.; El-Ramady, H.; Alshaal, T.; El-Garawany, M.; Elhawat, N.; Al-Otaibi, A. Silica nanoparticles boost growth and productivity of cucumber under water deficit and salinity stresses by balancing nutrients uptake. Plant Physiol. Biochem. 2019, 139, 1-10. [CrossRef]

53. Das, K.; Roychoudhury, A. Reactive oxygen species (ROS) and response of antioxidants as ROS-scavengers during environmental stress in plants. Front. Environ. Sci. 2014, 2, 53. [CrossRef]

54. Garg, N.; Manchanda, G. ROS generation in plants: Boon or bane? Plant Biosyst. 2009, 143, 81-96. [CrossRef]

55. Sarker, U.; Oba, S. Catalase, superoxide dismutase and ascorbate-glutathione cycle enzymes confer drought tolerance of Amaranthus tricolor. Sci. Rep. 2018, 8, 1-12. [CrossRef]

56. Gill, S.S.; Tuteja, N. Reactive oxygen species and antioxidant machinery in abiotic stress tolerance in crop plants. Plant Physiol. Biochem. 2010, 48, 909-930. [CrossRef]

57. Miller, J.N.; Rice-Evans, A.C. Factors influencing the antioxidant activity determined by the ABTS•+ radical cation assay. Free Radic. Res. 1997, 26, 195-199. [CrossRef]

58. Behboudi, F.; Tahmasebi Sarvestani, S.; Kassaee, M.Z.; Modares Sanavi, S.A.M.; Sorooshzadeh, A. Improving growth and yield of wheat under drought stress via application of $\mathrm{SiO}_{2}$ nanoparticles. J. Agric. Sci. Technol. 2018, 20, 1479-1492.

59. Noctor, G.; Veljovic-Jovanovic, S.; Driscoll, S.; Novitskaya, L.; Foyer, H.C. Drought and oxidative load in the leaves of C3 plants: A predominant role for photorespiration? Ann. Bot. 2002, 89, 841-850. [CrossRef]

60. Ayala, A.; Munoz, F.M.; Arguelles, S. Lipid peroxidation: Production, metabolism, and signaling mechanisms of malondialdehyde and 4-hydroxy-2-nonenal. Oxid. Med. Cell. Longev. 2014, 2014, 360438. [CrossRef] [PubMed]

61. Grela, R.E.; Samolinska, W.; Kiczorowska, B.; Klebaniuk, R.; Kiczorowski, P. Content of minerals and fatty acids and their correlation with phytochemical compounds and antioxidant activity of Leguminous seeds. Biol. Trace Elem. Res. 2017, 180, 338-348. [CrossRef] [PubMed]

62. Hussain, B.; Lin, Q.; Hamid, Y.; Sanaullah, M.; Di, L.; Khan, B.M.; He, Z.; Yang, X. Foliage application of selenium and silicon nanoparticles alleviates $\mathrm{Cd}$ and $\mathrm{Pb}$ toxicity in rice (Oryza sativa L.). Sci. Total Environ. 2020, 712, 136497. [CrossRef]

63. Rehman, U.S.; Bilal, M.R.; Rana, M.R.; Tahir, N.M.; Shah, N.M.K.; Ayalew, H.; Yan, G. Cell membrane stability and chlorophyll content variation in wheat (Triticum aestivum) genotypes under conditions of heat and drought. Crop Pasture Sci. 2016, 67, 712-718. [CrossRef]

64. Mateos-Naranjo, E.; Andrades-Moreno, L.; Davy, A.J. Silicon alleviates deleterious effects of high salinity on the halophytic grass Spartina densiflora. Plant Physiol. Biochem. 2013, 63, 115-121. [CrossRef]

65. Xu, W.; Cui, K.; Xu, A.; Nie, L.; Huang, J.; Peng, S. Drought stress condition increases root to shoot ratio via alteration of carbohydrate partitioning and enzymatic activity in rice seedlings. Acta Physiol. Plant. 2015, 37, 9. [CrossRef] 